\title{
ELEGIES AND GENEALOGIES OF PLACE: SPATIAL BELONGING IN ITALIAN/AMERICAN CULTURE AND LITERATURE
}

\author{
ELEGÍAS Y GENEALOGÍAS DEL ESPACIO: \\ PERTENENCIA ESPACIAL EN LA CULTURA \\ Y LITERATURA ITALOAMERICANAS
}

\author{
EVA PELAYO SAÑUDO \\ Universidad de Cantabria \\ eva.pelayo@unican.es
}

\begin{abstract}
This article examines the poetics and politics of place in Italian/American culture and in Tina De Rosa's novel Paper Fish (1980), particularly its portrayal of 'elegies and genealogies of place', an appropriate framework through which to read the importance of spatial belonging. It investigates the way in which cultural identity is mostly built on both imagined communities and imagined places, as is common in migrant and diasporic cultures, through the evocation or creation of ancestors and the homeland. In addition, the Italian/American community leaves the characteristic Little Italy enclaves or undergoes displacement due to urban renewal projects and the move to the suburbs in the mid-twentieth century, which is sometimes compared to a second migration or diaspora. As a consequence, former urban enclaves come to assume a centrality as lost sanctuaries, which is captured in the trope of the Old Neighbourhood. The article contributes to existing contemporary research on the binomial placeidentity by tracing how key events of US urban history impacted on Italian/ American culture. Furthermore, the goal is to offer new critical readings of Paper Fish through the focus on place-making.
\end{abstract}

Keywords: Italian/American culture, Little Italy, (sub)urban migrations, imagined places, place-making. 


\section{Eva Pelayo Sañudo}

\section{Resumen}

Este artículo examina la poética y la política espaciales en la cultura italoamericana y en la novela Paper Fish (1980), de Tina De Rosa, particularmente la representación de las 'elegías y genealogías del espacio', que suponen un marco apropiado para el estudio de pertenencia identitaria a los lugares. Se analiza el modo en que la identidad cultural se construye principalmente a partir de comunidades y lugares imaginados, como sucede en los grupos migrantes y diaspóricos, a través de la evocación o creación de sus antepasados y de la tierra natal. Además, la comunidad italoamericana abandona los enclaves característicos de Little Italy puesto que sufre una expulsión debido a los proyectos de renovación urbana o se traslada a los suburbios a mediados del siglo XX, desplazamientos que a veces se comparan con una segunda migración o diáspora. En consecuencia, los enclaves urbanos tradicionales asumen una centralidad destacada como santuarios perdidos que se refleja en la recurrencia de alusiones al 'Antiguo Barrio' (Old Neighbourhood). El artículo contribuye a la investigación contemporánea existente acerca del binomio identidad-espacio al examinar cómo los eventos clave de la historia urbana de Estados Unidos impactaron en la cultura italoamericana. Por último, el objetivo es ofrecer nuevas lecturas y aproximaciones críticas de Paper Fish a través de la perspectiva de la construcción espacial (place-making).

Palabras clave: cultura italoamericana, Little Italy, migraciones (sub)urbanas, lugares imaginados, construcción espacial.

When an accidental detour or a missed expressway exit brings us into contact with the world we left behind, we can still place all the blame firmly and squarely elsewhere.

(Ray Suárez, The Old Neighborhood)

\section{The Development of Little Italies in North America: Place and Ethnic Identity}

This article provides a review of the scholarship about Italian/American identity and of its links with US urban history before moving on to a literary exploration of the topic through Tina de Rosa's novel Paper Fish (1980) in order to contextualize the impact of spatial changes depicted therein. ' To this end, sociological studies, cultural geography and feminist urban theory are used to read a novel which has been thoroughly examined by Italian/American scholars. Yet, a focus on the concept of place-making has drawn less critical attention. Although 


\section{Elegies and Genealogies of Place}

place-making is an everyday practice and particularly common to reflect identity politics, the spatial relevance in Paper Fish has not been sufficiently explored to explain the representation of Italian/American identity and its connection to key events in US urban history. In particular, this article contends that the theoretical perspective of place-making deeply informs the reinvention of ethnic identity, which is in turn affected by larger forces such as spatial exclusion and competition.

Definitions of Little Italy have considerably evolved from a simplistic linearity based on a trajectory of immigration, assimilation and eventual displacement or relocation. Both historians and writers have contributed to a redefinition of place that complicates traditional conceptions of these stages. For this reason, it is important to critically address the Italian/American spatial imagination and history. In William Boelhower's opinion, Little Italy should be regarded as a construct in its representation of a dominant, coherent culture that scholarship has privileged or contributed to establish. This configuration emerged to fulfill a necessary "collective subject" linked to the newly-formed demographic space in the United States after Italian immigration at the end of the nineteenth-century (2010:21). However, this unity was not achieved even in the case of intense urban concentration in the main cities of settlement such as New York. According to historians Philip Cannistraro and Gerald Meyer, "[c]ommunities were generally divided within themselves based on the place of origin of their residents" (2003: 11). The nascent Little Italies were mostly made up of relatives or people from the same regional villages. In other words, communities were rather fragmented, which was also due to the absence of other unifying organizations at the time.

Consequently, this prevailing model of unity shifted to account for perspectives that have come to complicate the homogenizing picture of the perception of Little Italy. Although (collective) identity is often linked to a certain material space known as Little Italy, this space has been more conceptualized in cultural terms. Little Italy is first and foremost conceived as socially interpreted and constantly reworked. This definition of Little Italy is also endorsed by Dennis Barone and Stefano Luconi when considering the "ethnic neighborhood as $[\ldots]$ an everevolving social construction more than a series of discrete geographical entities" (2010: 4). On the one hand, early ethnic formation undoubtedly demands a physical and geographic dimension. In the Italian/American case, it entailed "taking over a space demographically" (Boelhower 2010: 18), notably the area of Manhattan's Mulberry Bend in New York, where immigrants mostly settled because of work opportunities and the network of paesani who tended to foster further immigration: "this movement assumes the form of a convergence and creates a density that covers and inscribes a site so that it represents a recognizable degree of ethnic homogeneity" (18). On the other hand, Little Italy came to exist 


\section{Eva Pelayo Sañudo}

also discursively when assuming the cultural values of the home country in order to achieve a certain coherence. As such, this "symbolic confluence" underlying the concept of Little Italy in Italian/American historiography subsumed all differences in terms of gender, class or region, an integration or homogenization which has been recently questioned (18).

Boelhower has mostly credited the role of Italian/American women writers in unsettling those old notions of symbolic confluence through an "outpouring" of writing that "radically challenged the continuing validity of a merely collective, heavily patriarchal, and often mythologically sustained representation of 'Little Italy" (2010: 15). Additional perspectives are accounted for due to a "generational change-over" among writers and scholars of Italian/American culture and to a commonly shared sense of "leaving Little Italy" (15). Nevertheless, this is a very limited recognition and is uncritical of the suggested linearity of spatial configurations. For instance, historian Donna Gabaccia has variously addressed the complex Italian/American identity in relation to place, even before migration. Urban concentration or the typical ethnic enclaves of the US landscape, due to the compound factors of kinship ties and job opportunity, also feature in other chain migrations, chiefly Greek and Polish (King 1995: 17). The Italian localized sense of identity was further nuanced, given that the political and natural history in Italy had shaped Italians' conceptualization of place and of regional or local identity. Features of the home country's geography, such as mountainous and isolated places, together with abuse of the elite classes, account for the fact that trust was reserved for the more immediate kin, often the nuclear family, although kin partnerships were commonly enhanced in order to get diverse benefits. Similarly, the mass migration experience is commonly equated with the idea that Italy is a country in geographical more than national terms: an "abstraction" out of the fragmented history of foreign invasions and failed Unification (Gabaccia 2000: 1). In this respect, Gabaccia argues, "[i]t is no accident that the modern Italian word for country is the same as its word for village (paese)" (3), which makes her reframe her theoretical position of Italian migration as creating many diasporas (6).

This difference would then inform inter and intra-ethnic relations, as settlement and discrimination were played out in regional and more localized identities. On the one hand, as Gabaccia corroborates in relation to Sicilians and their major settlement in New York's Elizabeth Street, ${ }^{2}$ family refers not to the conjugal or nuclear unit but to the "lineal group of closest relatives", which includes, for instance, parents of the couple and their siblings (1984: 4). On the other, as historian Rudolph Vecoli explains, not only were Sicilians most likely to be racialized in relation to Northern Italians, but they were equally distinguished within "regional antipathies among the Italians" (1999: x, emphasis added). In other words, regionalismo was 


\section{Elegies and Genealogies of Place}

"reflected in the geography of settlement, the social organizations, and even the churches of the Little Italies" (x). Furthermore, prior to Boelhower's essay about the shift from a unifying picture of Little Italy to models acknowledging differences, Robert Orsi's 1985 The Madonna of 115th Street: Faith and Community in Italian Harlem paid attention to the formation of ethnic as well as gender identity in relation to the intense expression of spatial belonging already apparent during early settlement. Recently, Gabaccia has also researched the "invention of the term Little Italy" from as early as the 1880 s, resulting in the creation of certain representations of ethnicity which have become enduring in the cultural imagination despite contradicting geographical evidence:

New Yorkers invented "Little Italy" but they long disagreed with urban tourists about its exact location. Still, from the moment of its origin, both visitors and natives of New York associated Little Italy with entertainment, spectacle, and the search for "safe danger". While the location of Little Italy changed over time, such associations with pleasure and crime have persisted, even as the neighborhood emptied of its immigrant residents. (2007: 7)

This proves that the idea of Little Italy has always been malleable or subject to ongoing (re)construction. Place-making continued when the Italian/American community or former immigrants started to leave Little Italy in significant numbers in the second half of the twentieth century and required a new project of identity. Traditional enclaves did not become simply extinguished as generally believed, given that they were transplanted to other (sub)urban areas or repopulated with new immigrants, for example after the other significant wave of Italian migration to the US in the post-II World War decades (Ruberto and Sciorra 2017: 9). In other words, at the same time that Italians were moving out, other demographic changes counteracted that decline. As a case in point, this post-war influx of Italian immigrants into neighborhoods such as New York's Bensonhurst eventually led to the emergence of Guido culture, which greatly revitalized and brought to public attention discussions of Italian/American ethnicity. As Donald Tricarico states, "[u]rban Italian American youth made a significant turn to popular American culture after World War II; Doo Wop mobilized a discernible youth culture practice in the 1950s and 1960s inside Italian American neighbourhoods" (2019: 31).

Yet, Italian/American culture and literature are certainly filled with that early act of departure, either real or figurative. They commonly refer to the resettlement from the old communities or enclaves to new spaces throughout the city, notably to the suburbs in the mid-twentieth century. This move is commonly associated with becoming 'white' and middle class, as in Mario Puzo's novel The Fortunate Pilgrim, which ends with Lucia Santa's satisfactory confirmation to her children that "yes, now they were on Long Island" (Puzo 2004: 276), a final hard-earned 


\section{Eva Pelayo Sañudo}

conquest away from the filthy and clamoring tenements in lower Manhattan. Fred Gardaphe notes that "the shift from urban to suburban ethnicity is the subject of the writing of many young Italian Americans who watched as their families moved from working-class to middle-class life" (2004: 39). As a consequence, it is no wonder that old neighborhoods or urban enclaves come to be depicted as (lost) "urban Edens" (158).

Together with the national development of urban renewal in American cities in the 1950s and 1960s, this relatively voluntary move to the suburbs was a significant episode in the decline of Italian/American ethnicity, equated with a second migration or diaspora (Hendin 2003: 14; Bona 2010: 139), and the disappearance of the enclave of Little Italy as it was known. A witness to "the death of Chicago's Little Italies", which were "under siege from urban 'renewal', highway construction and changing population patterns", Vecoli concludes that, as a phenomenon across the country, this "marked the end of the first chapter of the history of the Italians in America" (1996: 3-4). This interpretation and Boelhower's questions about the role of "the scattered children of immigrants" when they resort to the "ars inveniendi — the steeped commonplaces - of Italian-American culture" (2010: 16) reveal the crucial relationship between identity and place: from the tendency to regard cultures as placed to the practice of place-making in response to social and cultural changes. This is not to suggest that place-making is simply reactive, defensive or nostalgic. On the contrary, it is a quotidian and vernacular practice which is not limited to the work of elites or of published writers nor can it be exclusively associated to moments of crisis. For instance, Joseph Sciorra (2015: xvii) locates New York's Italian/American distinctive place-centred ethnicity as reflected in the urban building traditions, which express a combination of religious and secular landscapes.

However, as spatial exclusion, expulsion and competition are recurrent in US urban history, focusing on such heightened moments of place-making can help our understanding of how expressions of power (or powerlessness) are enacted or reflected through space. As Orsi states in his "The Religious Boundaries of an Inbetween People", Italian Americans (re)affirmed their identity through a 'sacralization' of the streets. Claiming whiteness and occupation of space in particular were strategies to distance themselves from their "dark-skinned" neighbours, to which they were closely associated not only because of urban contiguity and/or conviviality, but also due to racial prejudice (1999: 257). This shows that Italian/ American place-making operates within different scales and racialized contexts, which only seems to increase due to the more profound changes of the post-World War II era. As a result, the use of a theoretical framework of the poetics and politics of place allows us to better elucidate Italian/American identity and to analyze the importance of spatial belonging in the culture as well as the literary imagination. 


\section{The Poetics and Politics of Place: (Sub)urban Migrations}

Demographic and social changes lead to common anxieties of a shrinking identity as traditional place-bound identification and closely-knit living is gradually lost. Many Italian Americans experienced this loss first with migration from Italy to the US and later with the mid-twentieth century move to the suburbs. At the same time, empirical and theoretical evidence show that attachment to place evades any definite conclusions about the decline of ethnicity linked to displacement. For instance, a strong sense of place may derive from the lack of other cultural anchors or venues. This is expressed in Vecoli's concerns about the costs of urban renewal projects for the Italian/American community due to the absence of ethnic associations or a field of Italian/American studies in the 1950s. Nowadays, artistic preservation and support are identified as a primary site of ethnic identity, particularly for the new generations (Tamburri et al. 2000: 9). This confirms that writing, as much as place, figures as a cultural signifier in Italian/American ethnicity, although the latter retains a marked prominence.

In "New Cultures for Old", Stuart Hall explains the prevalence of certain practices in identity politics, namely the concepts of 'placed cultures' and place-making. In the obsession with "landscaping culture" he observes that the association of culture to place is very powerful or that place represents one of the "key discourses in the systems of meaning we call culture" (Hall 1995: 181). Hall also draws on the concept of 'imagined communities', as proposed by Benedict Anderson in 1983 , as the clearest illustration of this tendency in relation to the nation. In other words, place is a central narrative, as is language or religion, in the construction of cultural identity. Hall remarks that culture does not "really" need place: "cultures can be sustained by peoples who do not live in the same place and have never met" and yet "we continue to imagine cultures as 'placed', to landscape cultures in our mind's eye. They are 'imagined communities" (183, emphasis in original).

An illustration of the issues discussed so far can also be seen in Paper Fish (1980), the best-known novel by Tina De Rosa, which deals with the (re)invention of ethnic identity and larger urban changes in US society. It perfectly captures this tendency to "landscape cultural identities" and to "give them an imagined place or "home", thus abiding by a definition of culture and cultural identity as strongly bounded, that is, attached to a place (Hall 1995: 181, emphasis in original). This is so, Hall explains, since for some individuals place may be experienced as a genetic or biological fact, given that, traditionally, a given place has been "tied up with the sharing of the culture between members with a long and unbroken common genealogy, kinship, residence and descent" (181). As for cases of population 


\section{Eva Pelayo Sañudo}

dispersal, places are still important, if not more so, inasmuch as place-making symbolically allows necessary legitimizing projects, working "to stabilize cultures" and providing the possibility of "unified identities" (183). As David Storey states, "people behave territorially because they need to, or perceive the need to" (2001: 15). The defense of territory is not only a human instinct but also a tool of power, which is particularly evident in the case of nation-states and their shifting boundaries. In addition, this political dimension of place-making applies at different scales, "from the geopolitical strategies of superpowers down to the home and the workplace" (16). As displaced people typically tend to do, Italian Americans cling either to Italy -although often to a regional and very local sense of place for historical and geographical reasons - or to closely-knit communities that were formed in America and that soon acquired a physically and culturally marked dimension.

The strong sense of place in Paper Fish is unmistakeably linked to the identity politics of the ethnic community. It is a metanarrative about the attempt, through writing, to record a culture on the brink of dissolution by such a paramount transformation as that caused by urban renewal projects in US cities, a period that is now identified as a "second enforced migration" (Bona 2010: 139) or "second diaspora" (Hendin 2003: 14). Apart from urban mobility, social mobility was brought about by post-war economic prosperity that also extended to the Italians. These changes were accompanied by a loosening of the 'observable' traits of ethnic identity, as the second generation more generally melted into American middleclass values (Conzen et al. 1990: 42). As a result, ethnic recovery and affirmation is enacted by the third-generation main character Carmolina through recourse to oral stories told by a grandmother figure, grandma Doria, establishing a connection with an ancestral culture which also allows her to embrace a distinctly female tradition. Carmolina has a central role in recovering her cultural community and the demolished Little Italy in Chicago. As the Italian/American ghetto was cleared and "[n]o one snapped a picture" (De Rosa 2003: 117), she takes to writing from memory and storytelling to recover both her people's past and their literary tradition.

Hence, places have not become meaningless but are re-conceptualized. There are various strategies that are generally used to cope with social and cultural changes. Accounting for the processes and elements that play into the (re)creation of cultural identity, the role of memory and nostalgia attests to the relationship between power and place-making. Orsi notes how Italian parents started to create an image of Southern Italy in order to ensure that family order was maintained. Orsi admits this is "a violence of the imagination" characteristic of immigrant groups, using place as a means of discipline (1990: 135-136). The famed 


\section{Elegies and Genealogies of Place}

intergenerational conflict among Italian Harlemites —as Orsi is using Covello's papers, although he points to further evidence in other New York Italian communities -3 , is "inevitably cast in the idioms of geography" by recourse to the binary logic of opposites (Orsi 1990: 133, emphasis added):

Parents and children accounted for themselves - to each other and to themselvesby telling stories about different places. Conflict over the meaning of 'American' and 'Italy' (or 'Harlem' and the 'the South', or 'New York' and 'Puerto Rico') was the community's most intimate moral discourse: when the generations talked about these two places they were $[\ldots]$ marking the boundaries of acceptable and unacceptable behavior. (134)

Memory, therefore, is all about the present, since it is used to try to control children, mostly in fear of the erosion of the institution of the family, which has always relied on mutual dependence, particularly in the context of the industrial economy and immigrant difficulties therein: "The memories of 'Southern Italy' [...] were not frozen at the moment of the immigrant's departure, but in the moment they encountered their maturing children. 'Southern Italy', in other words, was born of fear, desire, and denial in East Harlem" (Orsi 1990: 140). By the same token, nostalgia, although reasonably reflecting immigrants' suffering, was also an apt instrument to be "transmuted into discipline" (138).

In Paper Fish, this "moral topography" is most obviously lacking (Orsi 1990: 137) due to an intergenerational lack of communication, which is expressed in "Part I. The Memory" through an insistence on the "surly silence" surrounding the immigrant father, Marco (De Rosa 2003: 4). By contrast, the first encounter of Carmolina with Italy is through a variety of audible artifacts, stories and songs, as well as food, through which "Grandma was making the world for her" (15). This transmitted memory of "how beautiful Italy was" (15) is mobilized as a way of coping with the identity divide Carmolina experiences as she observes her grandma's kitchen from her home and is distinctly aware of being sometimes on one side, sometimes on the other, and often not being able to tell the distinction. As is evident, this is not the Italy of the clichéd "bitter bread" and feudal/ government oppression that resurfaced in other migration memories (Barolini 1999: 29) and in historical accounts, but a country of sunny, soft landscapes and of mystical fantasies. Drawing on William Dalessio, this place-making is also to be understood in the context of the need to preserve ethnic identity. He describes the role of the grandmother as a whole as that of a "cultural harbinger", "by preparing edible signifying units of ethnicity" (2012: 12), particularly in the postwar period when Americanness and ethnicity were mutually exclusive and assimilation pressures were unshakeable. 


\section{Eva Pelayo Sañudo}

\section{The 'White Flight' and Urban Displacement: Gendering and Racializing Place}

Sometimes forced, sometimes voluntary, the diaspora to the suburbs represents a marked moment of assimilation for white ethnics, ${ }^{4}$ since traditional urban patterns and culture became dissolved. Dalessio specifically remarks on the postwar erosion of ethnicity with the demolition of ethnic neighborhoods, especially because of urban renewal projects in cities and also a generalized migration to the suburbs in the 1950s. For example, he refers to Peter Balakian's Black Dog of Fate: A Memoir on the Armenian experience, which strongly depicts cultural assimilation. This novel starts precisely at the moment when the family moves to suburbia, unlike De Rosa's Paper Fish, which ends at this point.

As the phenomenon of migration to the suburbs swept the whole country, it has strongly remained in the American imagination, mostly as a golden era of peaceful and communal urban living in the Old Neighbourhood. This is shown by the recollections and interviews in Ray Suárez's book by the same name. Yet, according to Suárez, there was also a "wild racial mythology that marked these same decades - the deep separation that actually existed between Americans" (1999: 13). Micaela Di Leonardo also emphasizes that "there was no "era of northern amity' prior to the civil rights movement and black power", given that the cities in the north showed a great deal of racial prejudice against blacks through riots and public policies, among others (1994: 175). All this did not preclude, however, that "those outside the white mainstream bought into the same bourgeois dreams as their distant neighbors" (Suárez 1999: 13).

On the one hand, the suburban home became an asset in the US, subsidized by the government and widely promoted as socially and morally superior. Postwar economic prosperity participated in the exploitation of this fundamental gendered spatial layout, since it represented an "ideal of mass consumption" that could redirect "defense industries into peacetime production of domestic appliances for millions of families" (Hayden 1980: S173). Karen Franck further explains that "The Suburban Sanctuary" implied not only "moral and religious beliefs about the nuclear family", but "a retreat from the world of work, public activities and all people unlike one's self and one's neighbors" (1997: 166). She presents the paradoxical "immoral consequences" of the ideal, as it promotes a life "free of fiscal or moral obligations to other people" (167). Suburban life was attractive since it avoided "encounters with the pain of others less fortunate or with situations less pleasant" (167). In other words, this appeal involves evading not only the stress and profanity of work and money, but also the contact and conflict with unknown or 'undesirable' people. In fact, this social ideal reveals a planned scheme 
to (re)distribute power relations, which clearly reveals a racial and class construction of place.

On the other hand, mid-century urban restructuring clearly attests to the practice of "Mapping the Pure and the Defiled" signaled by David Sibley to contend that the fear and exclusion of difference was spatially figured, enacted and reinforced. The suburban home combines a gender and a racial ideology, being a purified haven from the "defiled city" (2008: 386). The government budget for suburban housing widened the US racial gap, accounting for today's continuing disparity (Suárez 1999; McKenna 2008; David and Forbes 2016). Only a few African/Americans finally accessed the benefits of the GI Bill for housing, education and job placement given that, if formally eligible, they found many obstacles, "fighting the administration's arbitrary, discriminatory, and indifferent treatment" (Herbold 1994: 105). This uneven (welfare) distribution was indeed entrenched since, by the late 1960s, when the 'white flight' had already deteriorated the inner cities, welfare programs again benefited "poor whites" in the city (Di Leonardo 1994: 175, emphasis in original), money was not equally diverted to impoverished areas, mostly black, affected by urban renewal relocations. According to Micaela di Leonardo, urban renewal projects displaced African/American or Latino populations by two-thirds to "inhospitable, poorly built, and badly maintained government housing projects" (175).

Finally, ethnicity played a key role in the suburban ideal. The popularity of ethnic food was key to aiding the post-World War II reestablishment of traditional domestic ideology in the 1950s as it involved the call for feminine ornamental and elaborate cookery (Neuhaus 1999). According to Dalessio, De Rosa does not reproduce the joys of food preparation associated with ethnic identity, as Balakian does even in suburbia and having affirmed a desire to go mainstream (2012: 164). Paper Fish offers a disheartened portrayal of the rituals of domesticity through Carmolina's parents, Sarah and Marco, particularly from Sarah's perspective and her gender roles. This depiction also differs from other interpretations of women as cultural harbingers previously discussed. Dalessio reads Sarah's cultural alienation - being a Lithuanian forced to leave behind her ethnic heritage when marryingregarding her husband Marco's Italian background as a consequence of the family's observance of US gender ideology (2012: 58).

Rather than their different ethnicity, the separate spheres and roles of the male breadwinner and female childrearing account for their failed marriage. Marco does not enter the kitchen when his wife is cooking. There is a marked contrast to the Mexican immigrant couple of neighbors living downstairs who are shown sharing the kitchen space. This is reflective of Marco and Sarah having moved up the social ladder and adhering to a "postwar gender ideology, which sharply delineates a man's space from a woman's" (Dalessio 2012: 68). This marital 


\section{Eva Pelayo Sañudo}

situation is far from being represented as a benefit of having embraced mainstream values. In addition, the family cannot ultimately leave the ghetto and become suburbanites either, due to the social status of low-paid Marco which keeps the family at a distance from the rest of society. In Suárez's interviews, mobility appears as an assumed choice although "it is an option not as easily invoked across the racial divide or lower down the economic scale" (1999: 14). The socalled "factor-M" — standing for "movement, migration and mobility", which defines the American spirit - then proves to be very limited in light of the subject's location within the more prominent class, racial and gendered systems (Roberson 1998: 4).

\section{Elegies of Place: Leaving Little Italy}

This suburban migration, either due to a forced displacement or as part of the 'white flight', figures as a change that is deeply mourned. This is well captured in the sense of loss seen in Paper Fish or what Sandra Gilbert calls the "Elegy for a Distant Land", which refers to the lament for both the Italian mother country and the former urban neighborhood:

In the end, of course, the city razes the buildings of Berrywood Street as part of a project for 'urban renewal'. And in the end, therefore, Paper Fish becomes not just an elegy for 'the land that got lost across the sea' but also an elegy for the delights and despairs of the temporary encampment on whose 'pinched back porches' Italians strengthened and succored one another before inexorably drifting into the so-called melting pot of a sometimes all-too chilly New World. (2003: xv)

Elegiac sentiments are not only present in the fiction. As the interviews from Suárez's book show, the former residents' memories are expressed in the typical language of migration experiences. For instance, they remark on the motivations of "upward mobility" and the desire for children to do better, as recounted by Tom O'Connell, touring his old block in Chicago: "When we left in [19]76 [... I raised seven kids here [...] we had one more after that" (Suárez 1999: 16). As with general migration movements too,${ }^{5}$ beyond personal aspirations a motivating agent is also involved. As it is described, "the number one concern" for their move is security (20). This is intended to explain the "forces behind [the] white flight [which] were in part malign"; these forces included "panic peddlers", who unveiled how the worry of safety often spread around "neighborhoods targeted by business interests" (17). Quite often, this concern with security is a fallacy used to legitimize other underlying ideological reasons for urban planning. According to Charles Manelli's account in Suárez's book, which describes an overnight drastic change as "an exodus", the reason why the city of St Louis was transformed in only about 
five years was contagious panic at the unrecognition of the "same atmosphere" (23). By contrast, he perceives his times "like living in a small town", remarking that the whole city was made up of neighborhoods like that, or rather that it was "a big neighborhood", where everyone knew each other and "you could walk anyplace" (23). As a consequence, Manelli is profoundly haunted by the loss, given that, forty-five years later, he is "still poking around his old neighborhood in the car. He would drive by his house and take the car up the alleys where he played ball as a boy before the war" (23).

A sense of place remains meaningful, shown by psychological scars around a phenomenon which, as stated above, is "continuing to shape the country" (Suárez 1999: 2). Suárez' record shows "hundreds of people who mourn the loss of a sense of place tied to block, school, and neighborhood church" (25). This is nostalgia easily fed by the feeling that they were forced out, that "they were obeying the American siren call to mobility" (16). Suburbanization deeply affected or transformed ethnicity in particular, shaping later Italian/American relations to space, mostly in a nostalgic fashion or around a narrative of authenticity. Lament or blame articulate how this suburban migration significantly destroyed ethnic communities (Vecoli 1996: 3; Hendin 2003: 14; Bona 2010: 139; Dalessio 2012: 55 ), and that the former enclaves, if they have partially survived at all, are often no more than theme parks, that is, a marketed rendition of ethnicity for tourist purposes (Candeloro 2005: 249; Kosta 2014). However, the Old Neighborhood figures as a larger trope in the US imagination, which contextualizes the Italian/ American distinct spatial experience of fundamentally living in urban enclaves. In Frank Cavaioli's terms, they were "slow to leave the city" (2001: 6). Italian Americans are commonly said to be the last minority to abandon the city - e.g. as late as 1976 in O'Connell's above-cited account. This dominant, largely national narrative of an Old Neighborhood may also account for Italian/American representational practices or identity differences with respect to other literatures. In the Italian/American case, migration heightens a clinging attachment to place, although certainly reterritorialized, as (re)connection to ethnic identity is also facilitated through food and the memory of immigrant forebears, as well as through writing.

\section{Locating Identity: Place-Making and Cultural Change}

Geography has tended towards a revised conceptualization of space in a concomitant way to gender as categories of analysis. The by now familiar cultural turn in feminist and geographical research has shifted the focus from material critique towards the analysis of discourse and the basic connection with identity 


\section{Eva Pelayo Sañudo}

formation, reproduction and contestation. In this sense, the relation of place and identity has moved "beyond "culture", the transparent understanding of cultures as placed, denoting "the way [in which] space functions as a central organizing principle in the social sciences at the same time that it disappears from analytical purview" (Gupta and Ferguson 1992: 7). It is further argued that with postmodernity, "space has not become irrelevant, [but] it has been reterritorialized" (9, emphasis in original). This is especially marked by the heightened changes caused by globalization, which commonly assumes that an increased mobility has disrupted the stable or fixed —or so-imagined rather - sense of identity and place (Massey and Jess 1995). Yet, according to Linda McDowell (1999: 2-3), the significance of place has not only continued but been intensified, which is clearly manifested by revivals of ethnic nationalisms. Many scholars stress that a sense of place has not been destroyed but reconstructed, as has always been the case, since localities are fluid and produced as well as transformed through socio-spatial practices. This is a useful perspective for the study of Italian/American social and urban mobility, particularly during the white flight and urban renewal projects, as it explains their heightened sense of loss of cultural identity accompanying a relatively benign geographical dispersal:

while the settlers a century ago, and blacks, earlier this century left all that was familiar to start again in a strange new world, these modern migrants sometimes headed just a little past the city line. Their old world was not 'gone' but now just a car ride away. (Suárez 1999: 2)

People have "always been more mobile and identities less fixed" than assumed (Gupta and Ferguson 1992: 9, emphasis added), even though the singularly fast and generalized mobility of both people and products in the last decades "give[s] a profound sense of a loss of territorial roots, of an erosion of the cultural distinctiveness of place" (9). At the same time, "senses of place may become intense when those who feel they belong there feel threatened" (Rose 1995: 97). Hence, just as today's increasing indeterminacy of place ironically turns into an intensified attachment to place, so too formerly "displaced peoples cluster around remembered or imagined homelands [and] places" (Gupta and Ferguson 1992: 10-11). These are "imagined places" that function as "symbolic anchors" of equally "imagined communities" (10-11). As deduced from these scholarly observations, such an imagining of space is not normally arbitrary but a way of registering and coping with larger socio-structural forces.

The way in which places are imagined needs to be thought of as a relational expression, as McDowell contends in her assertion that "locales are constructed through social relations" (1999: 5). Notably, places are defined and maintained by exclusion and force, although she admits that the formation of boundaries is also 
enacted by subtle means. This is related to the conceptualization of territoriality as a "spatial form of power", even when this is not always that overt as in the case of states or street gangs claiming space (Storey 2001: 15). By considering place as a political and analytical tool, we can examine which processes of change are at play in the Italian/American communities, as well as responses to them. A representative case study is offered through the above-mentioned notion of the elegies of place and the consequences for Chicago's Little Italy arising from urban renewal projects that displaced the Italian/American community (Gilbert 2003: xv).

Spaces are certainly meaningful although not as the old truth had it, as an anchor or a 'neutral' background site on which to inscribe social and cultural differences, but as a political instrument and, for this reason, in continuous contestation and formation. Although there exist "regimes of places" — quite established sets of spatial configurations that tend to hold through time (McDowell 1999: 5) -, spatial meanings also constitute a means through which to claim and maintain power. This is illustrated by Talja Blokland's analysis (2009) of Italian/American historical narratives of place dominating or silencing other claims and meanings of place. Following Massey's concept of 'place-making' — that is, spatial meanings not as fundamental but as related to claims of power (2005: 179) — Blokland shows the extent to which space still matters or continues to play a role for Italian Americans despite geographical dispersion and demographic change. Mostly because of community or spatial loss, their particular practice of place-making and way of "doing community" is out by means of urban and public structures after the demolition of a neighborhood formerly known as Little Italy in order to construct a highway (Blokland 2009: 1607). Even when the place has been gentrified, Italian Americans consider themselves still the legitimate residents and manage to be regarded as such at the level of local polity and access to resources, in contrast to perceptions of African/American residents who are 'absent' in historical narratives. This signals the crucial role of spatial collective memories in accounting for the stratification of places.

In addition, this particular example in which Italian Americans remember their Little Italy community displaced by the construction of a highway displays a discourse organized around "oppositional images of place", which shows the way in which the "imagination of place is politicized" (Gupta and Ferguson 1992: 12). Those celebrating their former neighborhood in New Haven's Little Italy also resort to a view of place validated by history which, as Doreen Massey and Pat Jess explain (1995), is a common strategy in struggles for place and their use. These authors argue that the supposed history of a particular place should be seen in a particular way: as often relying on the erasure of other histories of place. Meanings of place are seen in light of the concept of "place-making" (Massey 1995: 68, 


\section{Eva Pelayo Sañudo}

emphasis in original), as they constitute narratives that work to establish strong associations of people and place, obliterating other voices.

A final example of the politics of space attests to the shift already identified by Gupta and Ferguson from the "power of topography" to the "topography of power" which has been concealed by the former (1992: 8). In other words, a focus on the binomial of space and power analyzes the "radical operation of interrogating the 'otherness' of the other, situating the production of cultural difference within the historical processes of a socially and spatially interconnected world" (16). It coincides with McDowell's or Massey's claims, among others, that there is no such thing as an autonomous space (Massey 1994: 5; McDowell 1999: 5). They disrupt such a fiction and establish the idea that places are (hierarchically) interconnected, which helps us better to understand social change and cultural transformation. Thus, as Suárez remarks, the postwar bourgeoning economy and economic benefits of the GI Bill meant that buying houses aided the migration to the suburbs. However, the racial construction of place proved key to selling the dream of suburban life, elucidating why the phenomenon is known as 'white flight': “as the cities that have become the home to the largest minority populations are consistently described as places of 'blight' and 'decay', the largest and fastest-growing cities, with few exceptions, are inhabited by whites in percentages higher than that of white people in the overall national population" (1999: 9). He adds that "one of the Great Migrations of American history" has shaken the country not only demographically but also socially and culturally (2).

The "ubiquity of place making" is enacted in a variety of collective projects, not limited to nationalism nor to the right, and including a politics of nostalgia (Gupta and Ferguson 1992: 13). As already mentioned, nostalgia, as well as memory and narration, are central in Italian/American place-making. As a representative example, in Paper Fish, oppositional images of place are expressed in the community's rendering of place as nurturing and innocent or defenseless versus investors' own perceptions deciding to raze the Italian enclave of Taylor Street in order to build the University of Chicago: "The city, you think she do it?' the seedman asked. 'You think she come tear us down like we a rotten building?"' (De Rosa 2003: 117). Since the city is personified as an all-powerful agent that comes to clear a people who are perceived as rotten in themselves and need to be pulled down, the novel as a whole constitutes an elegy of place. This pattern of place-making is a counter-narrative, given that the community is destroyed for commercial interests that resort to ethnic prejudice as legitimation. At the crucial moment of destruction, the neighbors show their astonishment and deliver contesting narratives: Stephanzo and Sophia decide to leave "piling full 


\section{Elegies and Genealogies of Place}

the truck with their pictures, the couch, the lamps, the children" as "the city she run over your children and smash them flat, like this $[. .$.$] They call us wops. They$ say these streets have to go" (118). Giovanni, by contrast, firmly admonishes them and decides to stay, thinking that "the city, she change her mind, then you be sorry" (118). To no avail, however, as he

went to sit alone on the concrete stoop of his house. Berrywood Street had disappeared as though it were a picture someone wiped away. The city said the Italian ghetto should go, and before the people could drop their forks next to their plates and say, pardon me?, the streets were cleared. (120)

As Doreen Massey (1995: 50) and Gillian Rose argue (1995: 97), place-making often functions as a "defense" or intensifies under feelings of "threat". For instance, senses of place are mobilized in order to avoid re-building or different people moving into a given neighborhood, as is the case in the novel. Similarly, the portrayal of a closely-knit, 'bounded' community through writing and memory represents a common articulation in the project of 'fixing' culture and identity as a way for people to "seize their destiny" in the face of destructive or dominant forces (Duncan and Duncan 2004: 393).

As mentioned earlier, today the prevalent spatial belief concerning Italian/ American spaces is that of theme parks, and many Little Italy enclaves are "decried as inauthentic" (Kosta 2014: 225). This is linked to an essentialist idea of ethnic identity which rather privileges 'visible' signs such as food, communal living, as well as close ties and very precise symbols (flags or music). The identity of place is also generally conceived in terms of authenticity, due to a similarly essentialist conceptualization of space as bounded and unchanging. This explains the widereaching phenomenon of "exclusivist claims to places - nationalist, regionalist and localist” (Massey 1994: 4). The extended belief of Italian/American conspicuous "attachment to place" and nostalgia is not unique, therefore, as individuals" general sense of a "place-bound identity" (4) is integrated into and mobilizes collective narratives of belonging.

Patterns of settlement and ethnic relations have mostly been conceived in terms of racial conflicts, although a critical analysis of spatial organization reveals fights for space deriving from the interests of power. The politics of space explains how such a fight is often as much over resources as over identity: "Who and what a city is for is a matter of diverse social, economic and cultural claims. These competing claims open onto conflicts over space and power, cut lines of division and difference in the city, and are fought over meaning and representation" (Tonkiss 2005: 63, emphasis in original). The characteristic sense of displacement experienced by Italian Americans in the second half of the twentieth century took place in light of economic and urban restructuring, as well as of new racial 


\section{Eva Pelayo Sañudo}

dynamics in the United States. According to Simone Cinotto, this "influx" of Italians to the suburbs, together with the "ethnic and racial succession" in the former enclaves as a consequence of the arrival of Puerto Ricans and African Americans from the rural South, entailed "resettling in second-migration areas" and "resuming the work of place-making" (2014: 167). As a result, "Italians emerged from the rapid process of urban change with the label of the toughest 'defenders of place' and most passionate 'lovers of place' among white ethnic groups, uncompromisingly, and even violently, upholding their ethnic-inflected working-class community life" (167). In this vein, to the binomial identity and sense of place, the related element of territory (Storey 2001: 15) is especially relevant to the discussion in that Italian/American strong sense of place is sometimes regarded in a pejorative way such as when they are referred to as 'territorial people'.

This territorial and political sense of place is not unique to Italian/American identity. The contributions by Monika Kaup in her study about the "architecture of ethnicity" (1997) and by Raúl Homero Villa on the concept of "place-identity" (2000: 5), which describe the emergence of Chicano history from the fight for space, can be useful as an approach to certain aspects of Italian/American spatial history. For instance, they contextualize the so-called sacralization of the streets (Orsi 2010: 183), which refers to Italian/American way of 'competing' for space and claiming belonging through religious festivals and processions. The comparison can also explain other geographical settlements and conceptions of place, notably the postwar suburban diaspora, other processes of urban restructuring and their (enduring) effects on Italian/American identity. This well-known white flight to the suburbs, for instance, is too easily taken for granted as voluntary, for example for social climbing or as a way of catching up with mainstream new ideals. Neighborhoods were also frequently destroyed for profitable building schemes, as argued by Jerome Krase regarding Chicago's shrinking Little Italies (1999). In addition, Italian Americans were not always that 'white' either (Guglielmo and Salerno 2003: 2), and the call to the suburbs, as was previously explained, was equally embedded in very distinct racial and gender discourses.

\section{Conclusion}

Renewal projects in US cities in the 1950s and 1960s represent a turning point often referred to as a second migration or enforced diaspora (Hendin 2003: 14; Bona 2010: 139). While at other times the Italian/American move to suburbia responded to less violent motivations, such as to conform to American ways and 


\section{Elegies and Genealogies of Place}

escape the inner-city, it is a fact that urban mobility accompanied social mobility, and these changes were expressed in a language standing for immigration and ethnic identity. As Matthew Jacobson affirms, the "equation of mobility and suburbanization with 'diaspora' - a dispersion from the 'promised land' of immigrant immediacy - says a great deal about the reveries of the second, third, and fourth generation at mid-century" (2009: 18). This explains a certain spatial prominence in the Italian/American imagination, portraying the urban enclave as a kind of ancestor or homeland. In addition, it invites fruitful comparison with other cultures in the US, given that the Old Neighborhood becomes a national narrative or, following literary scholar Marcus Klein, “[e]verybody wants a ghetto to look back to" (in Jacobson 2009: 18).

Suárez also shows that life in the Old Neighborhood is a US reality and a key element of its cultural imagination, since "one in seven of us can directly connect our lineage through just one city, Brooklyn" (1999: cover). He provides a compilation of statistical data, historical sources and individual recollections of people who describe an American way of life that has vanished. Starting around 1945, more marked since the mid-1960s, and extending well into the 1980s, this period is popularly identified as the "decline of urban America" (8), when "millions moved from central cities to newly created suburbs, and from the northeast quarter of the country to the south and west" (4). This also represented a change in the restructuring of the economy and the decline of old industry. Urban life was still in vogue, as demonstrated by the rise of cities in the west, such as Los Angeles, which by 1960 had grown by a third of its size and surpassed Philadelphia, until then the third in the top ten American cities in the Northeast or Midwest. This difference between the perception of an urban decline and the continuing growth of cities, therefore, merits an analysis of the constructions of place as this relates to cultural identity and, more importantly, to broader power relations.

The genealogy of place is worth analyzing for the way in which place matters in identity formation in a very broad sense, not only physically or literally but also fulfilling the work of cultural preservation. There is a considerable discursive dominance of the spatial and the street(s) in accounts by the Italian/American community. As De Rosa's Paper Fish clearly emphasizes, place is akin to a cultural ancestor and is equally important in the production of difference, in order to claim or (re)affirm distinctive legacies within the framework of identity politics. Space is firmly linked to the (re)invention of ethnic and gender traditions through generational and genealogical discourse. That is to say, evocation of and attachment to place is not simply a manifestation of Italian/American history and culture or of a vanished past that needs to be recovered, but an expression of place-making and of the future. 


\section{Eva Pelayo Sañudo}

\section{Notes}

1. I am following Anthony J. Tamburri's (1991: 11) cautions on the ideological charge of the hyphen and using instead his proposed slash when 'Italian American' is employed as an adjective.

2. Maria Laurino also notes that "each block tended to attract specific regions from Italy". Apart from the Sicilians' wellknown settlement 'district', she reports that "Mulberry Street tended to be Neapolitan [...] in the newly defined boundaries of Manhattan's narrow streets" (2015: 43).

3. Leonard Covello is the famous Italian/American educator who devised community and Italian-oriented programs as a way to solve this 'intergenerational crisis'. Orsi refers to his memories in The Heart is the

bring immigrant parents and their New-York bring immigrant parents and their New-York children to some understanding of each other" (1990: 134).

\section{Works Cited}

ANDERSon, Benedict. (1983) 1991. Imagined Communities. Reflections on the Origin and Spread of Nationalism. London: Verso.

Barolinı, Helen. (1979) 1999. Umbertina. New York: The Feminist Press.

BARone, Dennis and Stefano Luconi. (eds.) 2010. Small Towns, Big Cities: The Urban Experience of Italian Americans. New York: American Italian Historical Association.

BLOKLAND,Talja. 2009. “Celebrating Local Histories and Defining Neighborhood Communities: Place-Making in a Gentrified Neighborhood". Urban Studies 46 (8): 1593-1610.

BoelhoWer, William. 2010. "Figuring Out Little Italy: Down Mott Street and into the City". In Barone, Dennis and Stefano Luconi (eds.)
${ }^{4}$. This is how European/American groups came to be defined in the late 1960s and 1970s. The cultural terrain of the new civil rights movements since the late 1960s had a big impact for former immigrants or groups of a European background to (re)affirm their identities, marking a new period in US racial history known as the white revival (Jacobson 2009). This ethnic renaissance, as it was also known, unfolded as a response to the stigmatization of Italians, a racialization and discrimination which, if not depriving them of basic rights, forced many to assimilate, for example in terms of the general abandoning of their language and cultural traditions.

5. See, for instance, Saskia Sassen for some transnational perspectives on migration that aim to explain this not only as a matter of personal choice, but as "the intersection of a number of economic and geopolitical processes that link the countries involved" (1999: 1).
SmallTowns, Big Cities:The Urban Experience of Italian Americans. New York: American Italian Historical Association: 15-31.

BonA, Mary Jo. 2010. By the Breath of Their Mouths: Narratives of Resistance in Italian America. New York: State University of New York Press.

Candeloro, Domenic. 2005. "Italian Americans". In Buenker, John D. and Lorman Ratner (eds.) Multiculturalism in the United States: A Comparative Guide to Acculturation and Ethnicity. Connecticut and London: Greenwood Press: 233-257.

Cannistraro, Philip V. and Gerald Meyer. (eds.) 2003. The Lost World of Italian American Radicalism: Politics, Labor and Culture. Westpot: Praeger. 


\section{Elegies and Genealogies of Place}

CAvaioli, Frank. 2001. "At the Millenium". In History of the Annual Conference of the American Italian Historical Association. Illinois: American Italian Historical Association: 1-24.

Cinotro, Simone. (ed.) 2014. Making Italian America: Consumer Culture and the Production of Ethnic Identities. New York: Fordham U.P.

Conzen, Kathleen, David Gerber, Ewa Morawska, George Pozetta and Rudolph Vecoli. 1990. "The Invention of Ethnicity: A Perspective from the U.S". Altreitalie 3: 37-62.

Dalessio, William R. 2012. Are We What We Eat? Food and Identity in Late Twentieth-Century American Ethnic Literature. Amherst, New York: Cambria.

DAVID, Gabrielle and Sean F. ForBes. (eds.) 2016. What Does it Mean to Be White in America? Breaking the White Code of Silence. New York: 2Feaf.

De RosA, Tina. (1980) 2003. Paper Fish. New York: The Feminist Press.

Di Leonardo, Micaela. 1994. "White Ethnicities, Identity Politics, and Baby Bear's Chair". Social Text 41: 165-191.

Duncan, James S. and Nancy G. Duncan. 2004. "Culture Unbound". Environment and Planning A 36 (3): 391-403.

FRANCK, Karen A. 1997. "The Suburban Sanctuary". Evolving Environmental Ideals, Stockholm: International Association for PeopleEnvironment Studies (IAPS) 14: 165-169.

GaBACCIA, Donna. 1984. From Sicily to Elizabeth Street: Housing and Social Change among Italian Immigrants, 1880-1930. Albany, New York: State University of New York Press.

GABACCIA, Donna. 2000. Italy's Many Diasporas. London:Taylor and Francis.

GaBACCIA, Donna. 2007. "Inventing 'Little Italy'". The Journal of the Gilded Age and Progressive Era 6 (1): 7-41.

GARDAPHE, Fred L. 2004. Leaving Little Italy: Essaying Italian American Culture. New York: State University of New York Press.

GILBERT, Sandra M. 2003. "Foreword: Elegy for a Distant Land". In De Rosa, Tina. Paper Fish. New York: The Feminist Press: ix-xv.
Guglielmo, Jennifer and Salvatore Salerno. 2003. Are Italians White? How Race is Made in America. New York: Routledge.

GuptA, Akhil and James Ferguson. 1992. "Beyond 'Culture': Space, Identity, and the Politics of Difference". Cultural Anthropology 7 (2): 6-23.

HaLL, Stuart. 1995. "New Cultures for Old". In Massey, Doreen B. and Pat M. Jess (eds.): 175215.

HAYDEN, Dolores. 1980. "What Would a NonSexist City Be Like? Speculations on Housing, Urban Design, and Human Work". Signs 5 (3): S170-S187.

Hendin, Josephine Gattuso. 2003. "Social Constructions and Aesthetic Achievements: Italian American Writing as Ethnic Art". MELUS 28 (3): 13-39.

Herbold, Hilary. 1994. "Never a Level Playing Field: Blacks and the GI Bill". The Journal of Blacks in Higher Education 6: 104-108.

JacoBson, Matthew F. 2009. Roots Too: White Ethnic Revival in Post-Civil Rights America. Cambridge and London: Harvard U.P.

KaUP, Monika. 1997. "The Architecture of Ethnicity in Chicano Literature". American Literature 69 (2): 361-397.

KING, Russell. 1995. “Migrations, Globalization and Place." In Massey, Doreen and Pat M. Jess (eds): 5-44.

Kosta, Ervin. 2014. “The Immigrant Enclave as Theme Park: Culture, Capital, and Urban Change in New York's Little Italies". In Cinotto, Simone (ed.) Making Italian America: Consumer Culture and the Production of Ethnic Identities. New York: Fordham U.P.: 225-244.

KRASE, Jerome. 1999. "The Present/Future of Little Italies". Brooklyn Journal of Social Semiotics Research 1 (1): 1-22.

LaURINo, Maria. 2015. The Italian Americans: A History. New York: Norton.

MASSEY, Doreen. 1994. Space, Place and Gender. Minneapolis: University of Minnesota Press.

MASSEY, Doreen. 1995. "The Conceptualization of Place". In Massey, Doreen B. and Pat M. Jess (eds.): 45-87. 


\section{Eva Pelayo Sañudo}

MASSEY, Doreen. 2005. For Space. London: Sage.

MAssey, Doreen and Pat M. Jess. 1995. A Place in the World? Places, Cultures and Globalization. Oxford: Oxford U.P.

McDowell, Linda. 1999. Gender, Identity and Place: Understanding Feminist Geographies. Minneapolis: University of Minnesota Press.

McKenna, Cyd. 2008. “The Homeownership Gap: How the Post-World War II GI Bill Shaped Modern Day Homeownership Patterns for Black and White Americans". Master's Thesis. Massachusetts Institute of Technology.

Neuhaus, Jessamyn. 1999. “The Way to a Man's Heart: Gender Roles, Domestic Ideology, and Cookbooks in the 1950s". Journal of Social History 32 (3): 529-555.

ORSI, Robert. 1990. "The Fault of Memory: 'Southern Italy' in the Imagination of Immigrants and the Lives of their Children in Italian Harlem, 1920-1945". Journal of Family History 15: 133-148.

ORSI, Robert. 1999. “The Religious Boundaries of an Inbetween People: Street Feste and the Problem of the Dark-Skinned Other in Italian Harlem, 1920-1990". In Orsi, Robert (ed.) Gods of the City: Religion and the American Urban Landscape. Bloomington: Indiana U.P.: 257288.

ORSI, Robert. (1985) 2010. The Madonna of 115th Street: Faith and Community in Italian Harlem, 1880-1950. New Haven:Yale U.P.

Puzo, Mario. (1965) 2004. The Fortunate Pilgrim. New York: Random House Digital.

Roberson, Susan L. 1998. Women, America, and Movement: Narratives of Relocation. Missouri: University of Missouri Press.

Rose, Gillian. 1995. "Place and Identity: A Sense of Place". In Massey, Doreen B. and Pat M. Jess (eds.): 87-132.

Ruberto, Laura and Joseph Sciorra. (eds.) 2017. New Italian Migrations to the United States. Vol. 1: Politics and History since 1945. Urbana: University of Illinois Press.

SASSEN, Saskia. 1999. Guests and Aliens. New York: The New Press.
ScIORRA, Joseph. 2015. Built with Faith: Italian American Imagination and Catholic Material Culture in New York City. Knoxville: University ofTennessee Press.

SIBLEY, David. 2008. "Mapping the Pure and the Defiled". In Oakes, Timothy S. and Patricia L. Price (eds.) The Cultural Geography Reader. London: Routledge: 380-387.

Storey, David. 2001. Territory: The Claiming of Space. Essex: Pearson.

SuÁrEZ, Ray. 1999. The Old Neighborhood: What We Lost in the Great Suburban Migration, 1966-1999. New York: The Free Press.

TAmburRI, Anthony J. 1991. To Hyphenate or Not to Hyphenate? The Italian/American Writer: An Other American. Montreal: Guernica.

Tamburri, Anthony J., Paolo A. Giordano and Fred L. GardaPhe. (eds.) (1991) 2000. From the Margin: Writings in Italian Americana. West Lafayette, Indiana: Purdue U.P.

TonkIss, Fran. 2005. Space, the City and Social Theory: Social Relations and Urban Forms. Malden, Massachusetts: Polity.

Tricarico, Donald. 2019. Guido Culture and Italian American Youth: From Bensonhurst to Jersey Shore. New York: Palgrave.

VeColl, Rudolph. 1996. "Are Italian Americans Just White Folks?" In Bona, Mary Jo and Tamburri, Anthony (eds.) Through the Looking Glass: Images of Italians and Italian Americans in the Media. Selected Essays from the $27^{\text {th }}$ Annual Conference of the American Italian Historical Association. Chicago: American Italian Historical Association: 3-18.

VECOLI, Rudolph. (1970) 1999. "Foreword". In Ets, Marie Hall (ed.) Rosa:The Life of an Italian Immigrant. Madison: University of Wisconsin Press: v-xi.

VILLA, Raúl Homero. 2000. Barrio-Logos: Space and Place in Urban Chicano Literature and Culture. Austin: University of Texas Press.

Received: 08/11/2019

Accepted: $20 / 02 / 2020$ 